\title{
Factors Affecting The Implementation Of Integrated Financial Management Informantion Systems In Selected County Governments Of Kenya
}

\author{
Valarie Ogachi ${ }^{1}$, DR. Willy Muturi \\ ${ }^{1}$ Jomo Kenyatta University of Agriculture and Technology, Department of Procurement and Logistics, Nairobi, \\ Kenya \\ ${ }^{2}$ Jomo Kenyatta University of Agriculture and Technology, Kenya
}

\begin{abstract}
This study sought to find out the factors influencing the implementation of integrated financial management information systems (IFMIS) in Kenyan County governments i.e. Kisii, Migori, Homabay, Kericho and Nyamira Counties. Thoughthe Government of Kenya has realized the importance of IFMIS towards efficient and effective service delivery and though several studies and consultative workshops have been carried out in an effort to prepare a road map for implementation of these IFMIS applications, there has been numerous challenges. The methodology of this study has purely been qualitative. The study adoptedpurposive sampling to pick the respondents from a target population of 150 employees from the five counties. Data was obtained through primary data sources by means of face to face interviews guided by questionnaires administered to a selected sample. A total of 48 employees sampled from different departments has formed the respondents of this study. Regulators; telephonic and written submissions as well as secondary research in the form of literature reviews have been employed. The questionnaires were administered through drop and pick later method to the respondents. Descriptive and inferential statistics were used to analyze the data collected. In descriptive statistics, frequencies and percentageswere used. The findings were presented in tables and graphs. The findings of this study revealed that most counties did not have different strategic approaches to IFMIS implementation; the ICT platform for the roll out IFMIS is in place; there are no regular skills upgrading courses on IFMIS and no motivation to retain skilled personnel; the political class is not supportive of IFMIS implementation and the counties have not allocated enough resources towards implementation of IFMIS. This study recommends that for IFMIS implementation to be effective in the counties: the National Treasury and counties should organize regular skills upgrading courses on IFMIS; the ICT platform should be upgraded required to roll out IFMIS to the sub counties availed; and the counties should allocate more resources towards implementation of IFMIS.
\end{abstract}

Keywords: Organizational Strategy, Human Resource Capacity, Kenya

\section{Introduction}

According to both Dorotinsky (2003) and Rozner (2008), an IFMIS is an information system that tracks financial events and summarises financial information. It supports adequate management reporting, policy decisions, fiduciary responsibilities and the preparation of auditable financial statements. In its basic form, IFMISis little more than an accounting system configured to operate according to the needs and specifications of the environment in which it is installed (Rodin-Brown 2008). In general terms, it refers to the automating of financial operations. In the sphere of government operations, IFMIS refers to the computerisationof public financial management processes, from budget preparation and execution to accounting and reporting, with the help of an integrated system for the purpose of financial management (Arnety \& Wepukhulu, 2013).

The introduction of Integrated Financial Management Systems (IFMIS) has become a core component of financial reforms to promote efficiency, security of data management and comprehensive financial reporting (Peterson, 2006). According to Hove et al (2010) IFMIS provide an integrated computerized financial package to enhance the effectiveness and transparency of public resource management by computerizing the budget management and accounting system for a government. It consists of several core subsystems which plan, process and report on the use of public resources. The scope and functionality of IFMIS can vary across countries, but sub-systems normally include accounting, budgeting, cash management, debt management and related core treasury systems. In addition to these core sub- systems, some countries have chosen to expand their IFMIS with noncore subsystems such as tax administration, procurement management, asset management, human resource and pay roll systems, pension and social security systems and other possible areas seen as supporting the core modules. 


\section{Local Perspective of IFMIS Implementation}

The Kenya Government has implemented the Integrated Financial Management Information System (IFMIS) since the year 2005 as its sole accounting system. It was adopted as a result of the numerous benefits envisaged from its effective use. The Public Financial Reform Management (PFMR) Strategy Paper 2001-2006 recommended automation as well as integration of key government functions such as human resources payroll, accounting, procurement and budgeting citing transparency, better financial management and reporting as some of the benefits (GoK, 2001).

The Strategic Plan for GoK IFMIS (2011- 2015) outlines the development of the Integrated Financial Management System (IFMIS). At present the system is being re-engineering with the aim of improving systems for management and reporting of financial data and information for the Government of Kenya. The IFMIS implementation requirement in Kenya originated from the Ministry of Finance and Economic Planning ICT Master Plan 2001- 2005 that highlighted gaps and weaknesses within the SIBET system that was in use (Kwena, 2013). The master plan proposed development of different modules comprising: accounting, revenue management, asset management among others and establishment of interfaces with the National Bank Payment Information System, Kenya Revenue Authority (KRA) and the Ministry of Labour for payroll and human resource management modules. In collaboration with the Government of Kenya and Kenyan researchers and organizations, the IDRC team is identifying the social, technological and institutional structures required for successful ICT policy implementation helping develop effective implementation strategies and detailed plans raising IFMIS awareness through workshops and training for senior Government officials developing indicators for measuring the progress and impact of the policy's implementation and documenting the lessons learned from Kenya's policy process to help other African countries grappling with similar challenges (Kanyungi, 2014).

\section{Statement of the Problem}

In Kenya the National Treasury introduced the Integrated Financial Management Information system as a PFM reform initiative aimed at automating and streamlining Governments financial management processes and procedures (Njenga, 2013). The continued efforts of proper management of public funds have led to the need for the introduction of an IFMIS system in the County governments in the country (World Bank, 2014). Initially, the implementation was done correctly in some institutions for example in the Central bank but this has not been met with resounding success in the parastatals and has not attained most of the intended objectives. The implementation of such a project has proved to be a very demanding undertaking and has not been met with resounding success (Karanja \& Nganga, 2014). The Kenyan Government is involved in several projects and there are usually large amounts of funds involved in the projects. To ensure proper management of funds, efficiency and the effectiveness in the implementation of the projects is key because of the continued increase in demand for accountability. (IFMIS Report March2013).

The ICT infrastructure for IFMIS varies across countries, but normally it represents an enormous, complex, strategic reform process to enhance performance of IFMIS (Chêne 2009). The lack of clear government policy for training of staff members also pose a challenge to how effective the systems will be in the management of funds. Politicians are at the heart of management of project funds and are known to benefit largely through lack of accountability and the existence of bureaucratic systems and any PFM intends to introduce internal controls. The internal controls eliminate loop holes for misuse of the project funds and usually explain lack of political commitment in the implementation of IFMIS.Theproblem is centered on the determinants leading to inefficiencies which are still experienced in the performance of the IFMIS in Kenya (Fedha, 2014). It is in this spirit that the study intends to establish factors influencing the implementation of integrated financial management information systems in Kenyan County governments.

\section{General Objective}

This study's main aim was to establish the factors influencing implementation of Integrated Financial Management Information Systems in selected County governments in Kenya.

\section{Specific Objectives}

This study aimed to achieve the following two under listed objectives:

i. To establish how human resource capacity influences the implementation of Integrated Financial Management Information Systems in County governments in Kenya.

ii. To find out how theorganization strategy influences the implementation of Integrated Financial Management Information Systems in County governments in Kenya. 
Theoretical literature Review

The following theories and models constitute the theoretical framework on which this research study is built on.

\section{Last Planner Theory}

Organization is to ensure it has access to and control of valuable resources by developing and securing all the relevant resources either internally or externally. If a firm possess critical resources that have strategic value, it is better to retain the activity in house (Ullrich, 2013). On the contrary, if the strategic value of target activities is low and no internal resources are available to perform such activities, it is beneficial for the company to outsource them. For the sustainable competitive advantages, firms are forced to rely on a multitude of outside supplier for parts, software, knowledge and sales and in doing so gain access to valuable resources and external capabilities (Gariga\&Mele, 2013).

The source of an organization's competitive advantage lies mainly in how it exploits its distinctive internal resources and competencies, by setting strategic objectives based on what they enable it to (Gariga\&Mele, 2013). The resource-based approach starts with the organization's strengths and seeks an environment that will enable it exploit them by changing environments to suit what it does best rather than changing what it does best to fit the environment (Kehoe \& Wright, 2013). One of the key insights of the resourcebased view is that not all organizational resources are a potential source of competitive advantage (Hitt, 2011). The above theory relates to human resource capacity on performance of Integrated Financial M a n a g e me $\mathrm{nt}$ Information System implementation.

\section{New Public Management (NPM) Model}

NPM model introduced not just a different way of managing public services, but also the need for different financial management tools and techniques. Introduced initially in response to widespread public criticism of the public service, the overall ethos of the reforms is greater public sector efficiency (Pretorius and Pretorius, 2008). Manning (2001) explains that the model has two key tenets: allowing managers to manage and making managers accountable. Common objectives of NPM include: a management culture and orientation that is customer and results focused; structural or organizational alternatives that promote decentralized authority and control; and the separation of policy making from service delivery. There are also implicit expectations of greater operational efficiency and bureaucratic responsiveness to political principals.

Many African countries influenced by donors have also adopted some NPM type reforms, although in most cases with little real progress (ECA 2003). What is clear from available literature on NPFM reforms in OECD countries is that social, political and organizational issues affect public sector accounting and management, and influence the direction and speed of reforms (Pretorius and Pretorius, 2008). Newberry and Pallot (2005) conclude that while there has clearly been progress, initial expectations have not been met and some concerns have been raised about the increasing complexity of the financial management systems, actually reducing rather than enhancing political accountability and control. This model will help in understanding the importance of implementing IFMIS as a public financial management tool and the expectations from the reform process.

\section{Resource Based Theory}

The resource-based view (RBV) as a basis for the competitive advantage of a firm lies primarily in the application of a bundle of valuable tangible or intangible resources at the firm's disposal. To transform a shortrun competitive advantage into a sustained competitive advantage requires that these resources are heterogeneous in nature and not perfectly mobile. Effectively, this translates into valuable resources that are neither perfectly imitable nor substitutable without great effort. If these conditions hold, the bundle of resources can sustain the firm's above average returns (Crook et al., 2008).

An organization should exploit existing business opportunities using the present resources while generating and developing a new set of resources to sustain its competitiveness in the future market environments; hence, an organization should be engaged in resource management and resource development (Song et al., 2002). Their writings explain that in order to sustain the competitive advantage, it is crucial to develop resources that will strengthen the firm's ability to continue the superior performance. Any industry or market reflects high uncertainty and, in order to survive and stay ahead of competition, new resources become highly necessary. Finney et al. (2005) agrees, stating that the need to update resources is a major management task since all business environments reflect highly unpredictable market and environmental conditions. 


\section{Conceptual Framework}

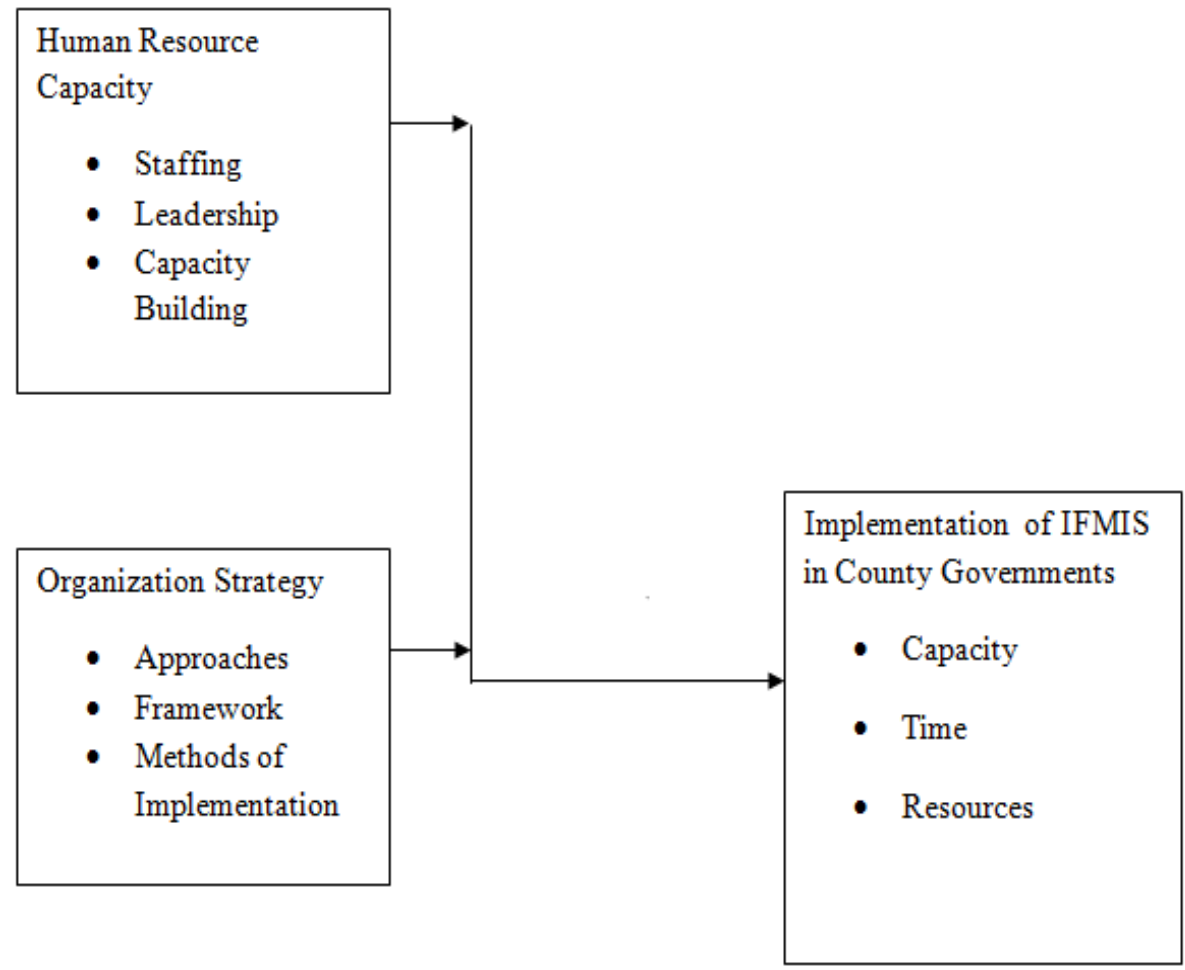

Figure 2.1 Conceptual Framework

\section{Empirical Review of Literature Human Resource Capacity}

According to Sanwal (2007) in a study on a study of modern, knowledge based organizations he

states that ideal settings for the application of strategic human resources management practices. Inasmuch as their competitive advantage is attributable to their people techniques which focus on people should prove to be directly linked to measures of organizational success. Civil service systems are designed to integrate the multiple values pursued by the public sector. While these rules can inhibit the adoption of progressive personnel practices, they are not the necessarily rigid barriers to change.

$\operatorname{ICPAK}(2014)$, in its baseline survey report on Devolution in Kenya with Respect to Public Financial Management Systems found that though most counties rated their interaction with IFMIS as proficient or good, there were some challenges noted. These include system user challenges due to limited practical training on some of the key modules installed. The study further recommended that regular training of County treasuries should be undertaken to enhance their technical skills in IFMIS.

The public sector has been the venue of many experiments and innovations in recent years. Social service agencies (such as those in studied here in (North Carolina) are indeed knowledge-based organizations. According to Theodore Lowi's (1972) policy typology, social services represent an effort at redistribution. While the agencies possess a professional, social science knowledge base, their redistributive objective remains controversial. In addition, the beneficiaries of this redistributive transfer from the haves to the have-nots are a politically marginalized segment of society (Mosher, 1968; Meier, 1987). Capacity building is a major factor affecting the success of IFMIS implementation, especially in developing countries (Chêne 2009). An IFMIS comprises more than only implementing a project; it also means planning for capacity building. A comprehensive training programme is therefore vital for the success of the project and should be compiled as early as possible. Training is essential to unlocking client readiness and is the best way to ensure sustainability of a system (Vickland\&Nieuwenhuijs, 2005).

\section{Organizational Strategy}

Chapman (2004) in a study titled: system failure: Why governments must learn to think differently recommended to start small at a realistic level and progressively expand the programmethrough the various layers of government. The first step consists of identifying an experimental entry level system limited to a pilot site, such as the Ministry of Finance, and to gradually consolidate and expand it to other institutions and levels of government. The system can then be successfully rolled out in phases once it has been tested and proven in this initial controlled environment. Change management and training of end 
users are important components of the roll-out strategy.

Wilson (2007) found that government regulation and policies can help ensure may be insufficient to achieve desired policy outcomes for example, in universal access which in the end contributes towards the growth of the sector. Wilson notes that many countries have established a regulatory authority separate from government and in charge of regulatory mechanisms to promote the use of ICTs such as licensing strategies, spectrum allocation, interconnection settlements, and dispute resolution, among others

Peterson (2006), in a study on Automating Public Financial Management in Developing Countries aimed at identifying frameworks for use in developing countries to ensure success in implementation of IFMIS projects. The conclusion from the study was that success of IFMIS depends on strong high level commitment and support, which is often lacking in DCs where bureaucratic rivalry, limited technical competence at the top and reluctance to change were factors. Further, the study recommended that long term high level commitment and acceptance and use by middle echelons of government was required for the success of financial reforms through information systems. Government officials, especially middle level managers need to see the need for the change and how the solution will help them.

Muriuki (2009) studied Challenges Facing the Ministry of Finance in The Adoption of Automated Financial System. The objective of the study was to determine the challenges facing the ministry of finance in managing change from legacy accounting systems to IFMIS. The study concluded that the major challenge was resistance to change brought about by fear of the unknown, not enough training, fear of redundancy and the fact that IFMIS ensured transparency leading to detection of fraud thus challenging the existing corrupt systems. It further recommended that ICT equipment and training be increased to boost employee awareness and that senior government officials show more support and commitment to the implementation of IFMIS.

\section{Implementation of IFMIS}

Diamond and Khemani (2005) studied the Introduction of Financial Management and Information Systems in Developing Countries. The aim of the study was to investigate the reasons for the almost universal failure to implement and sustain IFMIS in developing countries. The study concluded that though most developing countries had experienced limited success in the use of FMIS, there were a few success examples like Tanzania which had benefited extensively from the use of IFMIS. Examples of these benefits include: restoration of expenditure control, improved levels of transparency and accountability, elimination of over spending, reduction in the number of government accounts reduced to treasury single accounts, automatic reconciliation of banking data and fully reconciled fiscal data and reports are available on a continuous basis. The challenges identified included: lack of clarity in ownership of the system and unclear authority to implement, failure to clearly specify the basic functionality, failure to spend enough time on the design phase, failure to reengineer procedures, failure to undertake parallel reforms required by IFMIS in effective change management and lack of incentive for reforms.

Mutui (2014) analyzed the Effects of IFMIS on Procurement Performance of the Public Sector in Kenya. The study aimed at determining the extent at which IFMIS implementation had impacted on procurement performance in the public sector in Kenya. The objectives of the study were: to determine the extent to which government ministries in Kenya have implemented IFMIS in procurement; to establish the factors affecting implementation of IFMIS on procurement performance; and to assess the effect of IFMIS on procurement performance in the government ministries in Kenya. The study concluded that the implementation of IFMIS affects the overall procurement performance in the government ministries to a great extent and that the level of implementation of IFMIS was moderate. In addition, the benefits of IFMIS realized in procurement included: effective control over public finances, enhancement of transparency and accountability and serves as a deterrent to corruption and fraud. However some challenges experienced included: lack of capacity, a lack of commitment, and institutional and technical challenges. Further, the study recommended that the government review prohibitive legislations relating to public procurement and information management. A strong policy and legal framework supporting IFMIS should also be put in place and also the requisite infrastructure.

\section{Research Methodology}

\section{Research Design}

This study employed a descriptive approach on the factors influencing the implementation of Integrated Financial Management Information Systems in the County governments in Kenya. According to Mugenda\&Mugenda (2008), the purpose of descriptive research is to determine and report the way things are and it helps in establishing the current status of the population under study.

\section{Target Population}

The target population for this research study was150 employees of Migori, Kisii, Nyamira, Homabay and Kericho counties as shown in Table 1 below. 
Table 1 Target Population

\begin{tabular}{|l|l|}
\hline Department & No. of Employees \\
\hline County Executive Procurement Officers & 55 \\
\hline County Executive Accountants & 55 \\
\hline County Assembly Procurement Officers & 15 \\
\hline County Assembly Accountants & 15 \\
\hline County Assembly Accounting Officers & 5 \\
\hline County Executive Accounting Officers & 5 \\
\hline Total & 150 \\
\hline
\end{tabular}

\section{Source : Public Service Commission Annual Report ,2014}

\section{Sampling procedure and sample size}

A sampling frame is the source material or device from which a sample is drawn. It is a list of all those within a population who can be sampled, and may include individuals, households or institutions (Roger \&Jupp, 2006). The study had its sample frame from the employees of Migori, Homabay, Nyamira, Kericho and Kisii Counties.According to Warner \&Costenoble (2011), a sample size that surpasses the threshold of 30 respondents for a normal distribution is adequate for a study. According to Mugenda\&Mugenda (2008), a sample size of between $10-30 \%$ is a good representation of the target population and hence the $30 \%$ is adequate for analysis.

\section{Data collection procedure}

This research study used primary data. Primary data was collected by use of closed and open ended self administered questionnaires. According to Sekeran (2009) a questionnaire is a pre-formulated written set of questions to which respondents record their answers, usually within closely defined alternatives. The questionnaires were administered using a drop and pick later approach so that the respondents have ample time to answer the questions at their own convenient time.

\section{Data Analysis and Presentation}

Data collected was analysed using descriptive statistics. The descriptive statistical tools shall help in describing the data and determining the respondents' degree of agreement with the various statements under each factor. The study pursued the completed research instruments and document analysis recording sheets. Quantitative data collected using questionnaires wasanalyzed and was presented through percentages and frequencies. The information was also be displayed by use of frequency tables, charts and other figures applicable in data presentantion.

\section{Results And Discussion}

Descriptive statistics was used to discuss the findings of the study. The study targeted a sample size of 48 respondents from which 39 respondents filled and retuned the questionnaires making a response rate of 85.42.This response rate was satisfactory to make conclusions for the study as Cooper and Schneider (2003), states that a response rate of between 30 to $80 \%$ of the total sample size can be used to represent the opinion of the entire population.

\section{Human Resource Capacity}

Table 2: Human Resource Capacityassessment factors

\begin{tabular}{|c|c|c|c|c|c|c|}
\hline Human Resource Capacity assessment factors & Column & 1 & 2 & 3 & 4 & 5 \\
\hline \multirow[t]{2}{*}{ Staffing influences the performance of IFMIS } & Freq & 0 & 2 & 5 & 23 & 9 \\
\hline & $\%$ & 0.00 & 5.13 & 12.82 & 53.97 & 23.08 \\
\hline \multirow[t]{2}{*}{ Leadership is key to improved performance of IFMIS } & Freq & 0 & 0 & 3 & 31 & 5 \\
\hline & $\%$ & 0.00 & 0.00 & 7.69 & 79.49 & 12.82 \\
\hline \multirow[t]{2}{*}{ Staff capacity building influences the performance of IFMIS } & Freq & 1 & 4 & 7 & 20 & 7 \\
\hline & $\%$ & 2.56 & 10.26 & 17.95 & 51.28 & 17.95 \\
\hline \multirow[t]{2}{*}{ Team Building enables the performance of IFMIS to be better } & Freq & 30 & 2 & 5 & 2 & 0 \\
\hline & $\%$ & 76.92 & 5.13 & 12.82 & 5.13 & 0.00 \\
\hline
\end{tabular}

From the findings in the table 2 above, staffing influences the performance of IFMIS. Most respondents, $58.97 \%$ agree to a large extent on staffing influencing the performance of IFMIS while $23.08 \%$ of the respondents agree to a very large extent. Durevall and Erlandsson (2005) found that one of the reasons for failure of IFMIS in Malawi was due to the fact that the salary structures and terms of employment in government were not attractive and flexible enough to keep staff at the technical and professional level, when there were better employment opportunities in the private sector.

Majority of the respondents, $79.49 \%$ were of the opinion that leadership to a large extent is key to improved performance of IFMIS while $12.82 \%$ held the opinion that leadership is key to a very large extent. Chêne (2009) argues that the Ethiopian case study has proven that what matters most in the IFMIS 
implementation process is mid-level management's commitment to reform, as the changes ultimately have to be implemented at this level.

Staff capacity building influences the performance as represented by $51.28 \%$ of the respondents agreeing to a large extent, $17.95 \%$ agreeing to a very large extent while another $17.95 \%$ agreeing to a moderate. This agrees with Rodin-Brown (2008), capacity building and training need to be scoped out during the needs assessment process. Training programs need to address various audiences, from senior members of the bureaucracy down to mid- and entry-level civil servants. Rodin-Brown's (2008), assessment that given the nature of institutions and organizations, capacity building is a never-ending process that needs to be ongoing and permanent.

As to whether team building enables the use of IFMIS to be better, $76.92 \%$ of the respondents were of the opinion that it influences to a very small extent, $5.16 \%$ to a small extent while $12.82 \%$ agreed that it influences to a moderate extent.

\section{Organization Strategy}

This section sought to assess the effect that organization strategy to the implementation of IFMIS had on the effectiveness of the implementation process.

Table 5: Organization Strategy assessment factors

\begin{tabular}{|c|c|c|c|c|c|c|}
\hline Organization Strategy assessment factors & Column & 1 & 2 & 3 & 4 & 5 \\
\hline \multirow[t]{2}{*}{ Organization has different strategic approaches } & Freq & 32 & 5 & 2 & 0 & 0 \\
\hline & $\%$ & 82.05 & 12.82 & 5.13 & 0.00 & 0.00 \\
\hline \multirow[t]{2}{*}{ Organization framework allows for the use of IFMIS } & Freq & 24 & 9 & 6 & 0 & 0 \\
\hline & $\%$ & 61.54 & 23.08 & 15.38 & 0.00 & 0.00 \\
\hline \multirow[t]{2}{*}{ The methods of implementation of the strategy gives room for IFMIS } & Freq & 0 & 0 & 3 & 32 & 4 \\
\hline & $\%$ & 0.00 & 0.00 & 7.69 & 82.05 & 10.26 \\
\hline \multirow[t]{2}{*}{ There is a strategic fit between the organization strategy and IFMIS } & Freq & 0 & 0 & 5 & 28 & 6 \\
\hline & $\%$ & 0.00 & 0.00 & 12.82 & 71.79 & 15.39 \\
\hline
\end{tabular}

From table 4.7 above, the Counties do not have different strategic approaches. This is shown by $82.05 \%$ who agree to a very small extent and $12.82 \%$ who agree to a small extent, though a minority number at $5.13 \%$ agree to a moderate extent. It is clear that most Counties do not different strategic approaches as regards to IFMIS since they all comply with the circulars from National Treasury and CBK.

As to whether the organizational framework allowed for the use of IFMIS.Majority of the respondents were of the opinion that most individuals in management are not buying the idea of IFMIS usage. Only $15.38 \%$ of the respondents generally agree to a moderate extent, $61.54 \%$ agreed to a very small extent while $23.08 \%$ agreed to small extent. This implies that IFMIS implementation is facing resistance from individuals in management and they agree to its usage as a matter of compliance. This is contrary to the Miheso (2013) who found that having the users informed on how IFMIS will affect their current work is important in ensuring the success in the implementation as this will reduce resistance by the users and enhance acceptance of the new system.

A majority of respondents are of the opinion that the methods of implementation of the strategy gives room for IFMIS at the counties.82.05\% agree to a large extent and $10.26 \%$ agree to a very large extent while only $7.69 \%$ agree to a moderate extent. This implies that Counties are fully geared towards the implementation of IFMIS.

From the table above, only $12.82 \%$ of the respondents agree to a moderate extent that there is a strategic fit between the organization strategy and IFMIS with $71.79 \%$ agreeing to a large extent and $15.39 \%$ agreeing to a very large extent. The findings of this study indicate that there is a strategic fit between the organization strategy and IFMIS. This implies that the County governments have seriously embarked on rolling out IFMIS.

\section{Implementation of IFMIS by the County governments}

This section sought to assess the effect of the already implemented modules of IFMIS on PFM operations at the counties.

Table 6: Implementation of IFMIS by the County governments

\begin{tabular}{|l|l|l|l|l|l|l|}
\hline IFMIS implementation assessment factors & Column & 1 & 2 & 3 & 4 & 5 \\
\hline IFMIS is being implemented in phases & Freq & 0 & 0 & 0 & 27 & 12 \\
\hline & $\%$ & 0.00 & 0.00 & 0.00 & 69.23 & 30.77 \\
\hline Coordination among user departments. & Freq & 9 & 24 & 6 & 0 & 0 \\
\hline & $\%$ & 23.08 & 61.54 & 15.38 & 0.00 & 0.00 \\
\hline $\begin{array}{l}\text { Qualified personnel and adequate resources allocated to } \\
\text { IFMIS implementation. }\end{array}$ & Freq & 9 & 23 & 7 & 0 & 0 \\
\hline & $\%$ & 23.08 & 58.97 & 17.95 & 0.00 & 0.00 \\
\hline
\end{tabular}


As shown by table 6 above, majority of the respondents $69.23 \%$ agreed to IFMIS being implemented in phase while $30.77 \%$ agreed to a very large extent. This implies that no County has implemented all the IFMIS modules. For the IFMIS modules already implemented, it seems the system is working effectively and efficiently.

As to whether use of IFMIS has helped promoted coordination among user departments, $23.08 \%$ of the respondents are in agreement to a very small extent, $61.54 \%$ agreed to a small extent while $15.38 \%$ agreed to a moderate extent. There seems to be a general agreement that the use of IFMIS has not made coordination among user departments any easy.

The findings reveal that there are no adequate resources and qualified personnel allocated to IFMIS implementation. This can be shown by $23.08 \%$ of respondents who agree to a very small extent, $58.97 \%$ agreeing to a small extent and $17.95 \%$ agreeing to a moderate extent.

\section{Conclusion And Recommendations}

It is clear from the findings that most Counties do not have different strategic approaches towards IFMIS implemtantion. The Organizational framework existing in Counties is one that does not provide room for IFMIS use since most Counties are politically exposed hence the pressure from the politicians. There exists a strategic fit between strategy and IFMIS implementation sine his has to be done as a matter of compliance. These factors contributed to the resistance and negative attitudes towards IFMIS, thereby making the implementation process ineffective. According to Rodin-Brown (2008), the best way to overcome resistance is to sell the changes, relying on credible national resources to deliver the message. The selling can be done through a variety of media: workshops, seminars, training sessions, a website, conferences, or newsletters.

Human Resource capacity issues seem to be been dealt with properly. Most counties did provide adequate training on IFMIS to their staff; there are regularly planned skills upgrading courses for IFMIS hence capacity building; and team building is not encouraging coordination of user departments which in turn motivates employees to retain IFMIS trained staff in the counties. Rodin-Brown (2008) proposes that capacity building and training need to be scoped out early in the implementation process. The different user groups have to be identified; their levels of knowledge determined; recruiting needs established; and training curricula explored. Training programs need to address various audiences, from senior members of the bureaucracy down to mid- and entry-level civil servants. The use of IFMIS has not promoted coordination among user deparments, no adequate resources and qualified personnel allocated to IFMIS implementation in the Counties.

\section{Recommendations}

In general,the study recommends among other things that the Counties to have a more effective implementation of IFMIS, they should seek internal acceptance of IFMIS by all stakeholders by educating them more on the benefits.In order to a address the challenges of IFMIS implementation the researcher recommends the the Counties needs to have different strategic approaches.The different strategic approaches used should make sure all activities where possible are run within the IFMIS system to make it a true e-government system.The strategy should be designed to accommodate all financial transactions within the County government to reduce wastage and reduction of corruption.

The study recommends that the County Governements employ a change agent to oversee the implementation of the IFMIS and that users of the systems to undergo on the job training. Skills upgrading courses should be planned more regularly for staff working with IFMIS both by the counties and the National Treasury; and motivation provided to retain the trained staff in the counties. Effective management and team building efforts should be encouraged to allow rrom for coordination among departments.

\section{Suggestions for further research}

Since devolution is still a relatively new phenomenon in Kenya, and IFMIS was introduced shortly after, not many studies have dealt with the issue of IFMIS in the counties. Further research therefore, should be done on the impact of IFMIS on the public financial management of the County governments of Kenya; the influence of political will on effective implementation of IFMIS in the County governments of Kenya; and challenges faced by the County governments in the implementation of IFMIS.

\section{References}

[1]. Anca, V. A. C. A. R. (2013). Project Management-A Tool for Implementing Change In organizations. Studies in Business and Economics, 8(2), 137-144.

[2]. Afande, F. O. (2015). Adoption of E-Procurement Strategy and Procurement Performance in State Corporations in Kenya (A Case of KRA).

[3]. Amayi, F. K., \& Ngugi, G. K. (2013). Determinants of public procurement performance in Kenya: Case Ministry of Environment Water and Natural Resources. International Journal of Social Sciences and Entrepreneurship, 1(5), 647-667.

[4]. Ameen, A. A., \& Ahmad, K. (2011, November). The role of Finance Information Systems in anti-financial corruptions: A theoretical review. In Research and Innovation in Information Systems (ICRIIS), 2011 International Conference on(pp. 1-6). IEEE. 
[5]. Arnety, N. M., Ujunju, M. O., \& Wepukhulu, R. (2013). Effects of Business Process Re-engineering on Implementation of Financial Management Systems: A Case of Masinde Muliro University of Science and Technology. Research Journal of Finance and Accounting, 4(12), 90-96.

[6]. Atanda, A. I., \& Jaiyeoba, A. O. (2010). influence of academic staff knowledge, access and utilization of interactive whiteboard on teaching effectiveness in faculty of education, university of ibadan, ibadan, nigeria. East Africa Journal of Educational Research \& Policy, 4 .

[7]. Baker, D. L. (2009). Advancing E-Government performance in the United States through enhanced usability benchmarks. Government Information Quarterly, 26(1), 82-88.

[8]. Baloyi, L., \& Bekker, M. (2011). Causes of construction cost and time overruns: The 2010 FIFA World Cup stadia in South Africa. Acta Structilia,18(1), 51-67.

[9]. Bernard, H. R. (2011). Research methods in anthropology: Qualitative and quantitative approaches. Rowman Altamira.

[10]. Brown-Jeffy, S., \& Cooper, J. E. (2011). Toward a conceptual framework of culturally relevant pedagogy: An overview of the conceptual and theoretical literature. Teacher Education Quarterly, 65-84.

[11]. Berchicci, L. (2013). Towards an open R\&D system: Internal R\&D investment, external knowledge acquisition and innovative performance. Research Policy,42(1), 117-127.

[12]. Bukvova, H. (2009). Research as a process: A comparison between different research approaches (Vol. 9, No. 29, pp. 9-29). Sprouts: Working Papers on Information Systems.

[13]. Chene, M., \& Hodess, R. (2009). The Implementation of Integrated Financial Information Management Systems (IFMIS), Transparency International, 2 (1), 23-79. Doi: 1110g. jk5557x

[14]. Chettiparamb, A. (2013). Complexity theory and planning: Examining 'fractals' for organising policy domains in planning practice. Planning Theory, 1473095212469868.

[15]. Cope, D. R., Hills, P., \& James, P. (Eds.). (2013). Energy policy and land-use planning: an international perspective. Elsevier.

[16]. Creswell, J. W. (2013). Research design: Qualitative, quantitative, and mixed methods approaches. Sage publications.

[17]. Czarniawska, B. (2014). A theory of organizing. Edward Elgar Publishing.

[18]. Dener, C., Watkins, J., \& Dorotinsky, W. L. (2011). Financial Management Information Systems: 25 Years of World Bank Experience on What Works and What Doesn't. World Bank Publications.

[19]. Dorotinsky, B., \& Floyd, R. (2004). Public expenditure accountability in Africa: progress, lessons, and challenges. Building state capacity in Africa: New approaches, emerging lessons, 179-210.

[20]. Dorotinsky, W. (2003). Implementing financial management information system projects: The World Bank experience. World Bank.

[21]. Dzidonu, C. K. (2011). United Nations Department of Economic and Social Affairs (UNDESA), eGov Branch, New York, USA

[22]. Fedha, A. (2014). Influence of enterprise resource planning system on expenditure management at Kenya Sugar Research Foundation (Doctoral dissertation, University of Nairobi).

[23]. Feldman, S. (Ed.). (2013). Cognitive consistency: Motivational antecedents and behavioral consequents. Academic Press.

[24]. Foss, N. J., \& Knudsen, C. (2013). Towards a competence theory of the firm. Routledge.

[25]. Garriga, E., \& Melé, D. (2013). Corporate social responsibility theories: Mapping the territory. In Citation Classics from the Journal of Business Ethics(pp. 69-96). Springer Netherlands.

[26]. Gallarza, M. G., Saura, I. G., \& Garcia, H. C. (2002). Destination image: Towards a conceptual framework. Annals of tourism research, $29(1), 56-78$.

[27]. Gichoya, D. (2005). Factors affecting the successful implementation of ICT projects in government. theElectronic Journal of egovernment, 3(4), 175-184.

[28]. Gregor, S. (2006). The nature of theory in information systems. MIS quarterly, 611-642.

[29]. Hsin Chang, H., Tsai, Y. C., \& Hsu, C. H. (2013). E-procurement and supply chain performance. Supply Chain Management: An International Journal, 18(1), 34-51.

[30]. Heeks, R., \& Stanforth, C. (2007). Understanding e-Government project trajectories from an actor-network perspective. European Journal of Information Systems, 16(2), 165-177.

[31]. Hove, M. R., \& Wynne, A. (2010). The experience of medium term expenditure framework \& integrated financial management information system reforms in sub-Saharan Africa: what is the balance sheet?. African Capacity Building Foundation.

[32]. Holland, V. M., Sams, M. R., \& Kaplan, J. D. (2013). Intelligent language tutors: Theory shaping technology. Routledge.

[33]. Indeje, W. G., \& Zheng, Q. (2010, September). Organizational culture and information systems implementation: A structuration theory perspective. InIEEE International Conference on Information and Financial Engineering ChongqingChina (pp. 17-19).

[34]. Janita, M. S., \& Miranda, F. J. (2013). Exploring service quality dimensions in b2b e-marketplaces. Journal of Electronic Commerce Research, 14(4), 363-386.

[35]. Kamara, L. (2011). Challenges and Prospects of Establishing e-government in Liberia with focus on the Ministry of Finance, Ministry of Commerce and the Ministry of Planning and Economic Affairs of the Republic of Liberia.

[36]. Karanja, J. G., \& Nganga, E. N. (2014). Determinants of performance of Integrated Financial Management Information System in Kenya Government Ministries. Research journal of finance and accounting, 5(7).

[37]. Kehoe, R. R., \& Wright, P. M. (2013). The impact of high-performance human resource practices on employees' attitudes and behaviors. Journal of Management, 39(2), 366-391.

[38]. Kanyugi, A. M. (2014). A Framework For Determining The Level Of Success In The Implementation Of Karanja, J. G., \& Nganga, E. N. (2014). Determinants of performance of Integrated Financial Management Information System in Kenya Government Ministries. Research journal of finance and accounting, 5(7).Ifmis: A Case Of The National Treasury (Doctoral dissertation).

[39]. Kimwele, J. M. (2011). Determinants of performance of integrated financial management information systems (IFMIS) in government ministries in Kenya (Doctoral dissertation, University of Nairobi).

[40]. Kinoti, J. T. (2013). E-procurement Adoption By Government Parastatals In Kenya: The Supplier Perspective (Doctoral dissertation, University of Nairobi).

[41]. Korinek, A., \& Mendoza, E. G. (2013). From sudden stops to fisherian deflation: Quantitative theory and policy implications (No. w19362). National Bureau of Economic Research.

[42]. Kwena, F. I. (2013). Factors influencing the use of integrated financial management and information systems in public sector. a case of selected government ministries in Kenya (Doctoral dissertation).

[43]. Langley, A. N. N., Smallman, C., Tsoukas, H., \& Van de Ven, A. H. (2013). Process studies of change in organization and management: unveiling temporality, activity, and flow. Academy of Management Journal, 56(1), 1-13.

[44]. Le Coze, J. C. (2013). Outlines of a sensitising model for industrial safety assessment. Safety science, 51(1), $187-201$.

[45]. Liscic, B., Tensi, H. M., \&Luty, W. (Eds.). (2013). Theory and technology of quenching: a handbook. Springer Science \& Business Media. 
[46]. Matten, D., \& Moon, J. (2008). "Implicit" and "explicit" CSR: a conceptual framework for a comparative understanding of corporate social responsibility.Academy of management Review, 33(2), 404- 424.

[47]. Mugenda, O. M., \&Mugenda, A. G. (2008). Research Methodology, Qualitative and Quantitative Methods.

[48]. Muriuki, M. P. (2009). Challenges facing the ministry of finance in the adoption of automated financial systems (Doctoral dissertation)

[49]. Mutisya, J. M. (2014). Effects of an integrated revenue collection system and challenges facing its implementation in Machakos County (Doctoral dissertation, University of Nairobi).

[50]. Njenga, A. N. (2013). The relationship between financial management reforms and the economic performance of public sector in Kenya (Doctoral dissertation, University of Nairobi).

[51]. Njonde, J. N., \&Kimanzi, K. (2014). Effect of integrated financial management information system on performance of public sector: A case of Nairobi County Government. International Journal of Social Sciences and Entrepreneurship, 1 (12), 913-936.

[52]. Ochara, N. M. (2010). Assessing irreversibility of an E-Government project in Kenya: Implication for governance. Government Information Quarterly, 27(1), 89-97.

[53]. Odolo, I. A., \&Gekara, M. G. (2015). The effects of employee skill set in integrated financial management information system on service delivery in the ministry of interior and coordination of national government in kenya. european journal of business and social sciences, 4(04), 17-24.

[54]. O'Fallon, M. J., \& Butterfield, K. D. (2005). A review of the empirical ethical decision-making literature: 1996-2003. Journal of business ethics, 59(4), 375-413.

[55]. Ongaki, B. (2013). Factors affecting the use of information and communication technology in government parastatals a case of national environment management authority (Doctoral dissertation, KENYATTA UNIVERSITY).

[56]. O'Neil, H. F., \& Perez, R. S. (2013). Web-based learning: Theory, research, and practice. Routledge.

[57]. Orina, D. (2013). E-procurement readiness factors in kenya's Public sector(Doctoral dissertation, University of Nairobi).

[58]. Oyugi, L. N. (2008). Experiences with Medium-term Expenditure Framework in Selected Southern and Eastern African Countries: A Comparative Study for the Southern and Eastern Africa Policy Research Network. Southern and Eastern Africa Policy Research Network.

[59]. Peterson, S. (2006). Automating public financial management in developing countries. John F. Kennedy School of Government Working Paper No. RWP06-043.

[60]. Rozner, E. Li, Y., Qiu, L., Zhang, Y., Mahajan, R., \& (2008). Predictable performance optimization for wireless networks. ACM SIGCOMM Computer Communication Review, 38(4), 413-426.

[61]. Saurin, T. A., Wachs, P., \&Henriqson, It. (2013). RETRACTED: Identification of non-technical skills from the resilience engineering perspective: A case study of an electricity distributor. Safety science, 51(1), 37-48.

[62]. Sekaran, U., \&Bougie, R. (2003). Research methodology for business.

[63]. Selfano, O. F., Peninah, A., \& Sarah, C. (2014). Integrated Financial Management Information System and Its Effect on Cash Management in Eldoret West District Treasury, Kenya. International Journal of Business and Social Science, 5(8).

[64]. Sigei, S. C. (2013). Critical success factors in the implementation of the re-engineered integrated financial management information system in government ministries, Kenya (Doctoral dissertation, University of Nairobi).

[65]. Ulrich, D. (2013). Human resource champions: The next agenda for adding value and

[66]. Oyugi, L. N. (2008). Experiences with Medium-term Expenditure Framework in Selected Southern and Eastern African Countries: A Comparative Study for the Southern and Eastern Africa Policy Research Network. Southern and Eastern Africa Policy Research Network.

[67]. Peterson, S. (2006). Automating public financial management in developing countries. John F. Kennedy School of Government Working Paper No. RWP06-043.

[68]. Rozner, E. Li, Y., Qiu, L., Zhang, Y., Mahajan, R., \& (2008). Predictable performance optimization for wireless networks. ACM SIGCOMM Computer Communication Review, 38(4), 413-426.

[69]. Saurin, T. A., Wachs, P., \&Henriqson, It. (2013). RETRACTED: Identification of non-technical skills from the resilience engineering perspective: A case study of an electricity distributor. Safety science, 51(1), 37-48.

[70]. Sekaran, U., \&Bougie, R. (2003). Research methodology for business.

[71]. Selfano, O. F., Peninah, A., \& Sarah, C. (2014). Integrated Financial Management Information System and Its Effect on Cash Management in Eldoret West District Treasury, Kenya. International Journal of Business and Social Science, 5(8).

[72]. Sigei, S. C. (2013). Critical success factors in the implementation of the re-engineered integrated financial management information system in government ministries, Kenya (Doctoral dissertation, University of Nairobi).

[73]. Ulrich, D. (2013). Human resource champions: The next agenda for adding value and delivering results. Harvard Business Press.

[74]. Van Kamp, I., Leidelmeijer, K., Marsman, G., \& De Hollander, A. (2003). Urban environmental quality and human well-being: Towards a conceptual framework and demarcation of concepts; a literature study. Landscape and urban planning,65(1), 5-18.

[75]. Vehovar, V., \&Lesjak, D. (2007). Characteristics and impacts of ICT investments: perceptions among managers. Industrial Management \& Data Systems, 107(4), 537-550.

[76]. Vogel, R., \&Güttel, W. H. (2013). The dynamic capability view in strategic management: a bibliometricreview. International Journal of Management Reviews, 15(4), 426-446.

[77]. Waema, T. M., \&Adera, E. O. (2011). Local governance and ICTs in Africa: case studies and guidelines for implementation and evaluation. IDRC.

[78]. Wafula, J. M., \&Wanjohi, N. (2009). . ICT Policy and ICT Initiatives: What Linkages?.

[79]. Wynne, A. (2008). Accrual accounting for the public sector - a fad that has had its day. International Journal on Governmental Financial Management, 8(2), 117-132.

[80]. Yadav, M. S. (2010). The decline of conceptual articles and implications for knowledge development. Journal of Marketing, 74(1), 1-19.

[81]. Zakaria, W. Z. W., Rahman, S. F., \&Elsayed, M. (2011). An analysis of task performance outcomes through e-accounting in Malaysia. Journal of Public Administration and Governance, 1(2), Pages-124. 